\title{
BMG Global Heath Manmade earthquake: the hidden health effects of a blockade-induced fuel crisis in Nepal
}

\author{
Shyam Sundar Budhathoki, ${ }^{1}$ Hellen Gelband ${ }^{2}$
}

To cite: Budhathoki SS, Gelband H. Manmade earthquake: the hidden health effects of a blockade-induced fuel crisis in Nepal. BMJ Global Health 2016;1: e000116. doi:10.1136/ bmjgh-2016-000116

Received 25 June 2016 Revised 1 August 2016 Accepted 2 August 2016

${ }^{1}$ School of Public Health \& Community Medicine, B P Koirala Institute of Health Sciences, Dharan, Nepal ${ }^{2}$ Center for Disease Dynamics, Economics \& Policy, Washington DC, USA

Correspondence to Shyam Sundar Budhathoki; ss.budhathoki@gmail.com
My friend's uncle in his 50s living in Hetauda, Nepal had severe left-sided chest pain while working one evening. His colleague took him on a motorbike-twowheeler in local parlance-to a nearby hospital, arriving $45 \mathrm{~min}$ after the pain had started. The ECG and cardiac enzymes suggested an acute ST-elevated myocardial infarction. The hospital had no cardiologist or specialised services, and referred him to a hospital in the capital city, Kathmandu, $87 \mathrm{~km}$ away. However, no local ambulances were available for transporting the patient to Kathmandu. After frantically calling all contacts, a private ambulance from a city an hour away agreed to transport him on the condition that the patient supply $30 \mathrm{~L}$ of diesel. After an hour of searching, $25 \mathrm{~L}$ of diesel from the home of a local food retailer was arranged, at three times the regular price. Simultaneous with the search for fuel, the hospital staff was searching for a portable oxygen cylinder in the city to be sent with the ambulance, but ultimately failed. In the end, the patient travelled to Kathmandu without oxygen support. Thankfully, he reached the hospital, survived and is back to work in Hetauda.

This makes sense as a heroic story in the days after the devastating earthquake in Nepal in April 2015. But in fact, this happened in January 2016. It was a consequence of an entirely manmade disaster that barely caused a ripple in the international press: a blockade at the border inspired by India's unhappiness with provisions of Nepal's new constitution. The specific reason for the blockade was never satisfactorily explained, but it lasted for more than 5 months and caused severe difficulties in all facets of daily life. This is because Nepal, a landlocked country with no railroad, depends almost exclusively on petroleum driven transport, and petroleum and all other imports come into the country over the road from India.
Summary box

Border blockades in landlocked countries severely affect the daily lives of the people.

- The paper details the hidden effects of the recent political blockade in Nepal that led to a severe fuel crisis, dealing a blow to the health and well-being of a population still recovering from a major natural disaster.

- Border blockades and fuel crises, particularly in landlocked countries, lead to humanitarian emergencies that deserve attention equal to the attention paid to natural disasters.

The national financial loss due to the blockade is estimated at US $\$ 5$ billion, not so different from the losses incurred by the earthquake (US $\$ 7$ billion). ${ }^{1}$

Even less reported than the recent blockade was a 13-month blockade of Nepal by India 26 years ago, in 1989, also after a major earthquake. We suspect that the results were equally or more damaging, but frustratingly little was ever written about it. ${ }^{23}$

The 2015 earthquake killed almost 9000 and displaced 3.5 million people in rural mountainous and hilly areas, and in the densely populated capital city. In severely affected districts, more than $90 \%$ of the health facilities were either destroyed or seriously damaged. ${ }^{4}$ This destruction came on the heels of a decade of civil unrest that ended in 2008.

The blockade affected every aspect of life, bringing the country nearly to a standstill. People lined up for days just to receive a few litres of fuel. Factories shut down completely, schools and colleges were closed, and telecommunication services were on the verge of closing down. While there were ongoing political and diplomatic talks between Nepal and India, distribution of food and shelter aid to those affected by the earthquake was halted. No reconstruction materials could be provided. The ongoing humanitarian crisis 
caused by natural disaster was worsened by this manmade disaster, doubling the burden on regular and emergency health services. ${ }^{15-7}$

The healthcare system was hard hit. ${ }^{4}$ Ambulance services around the country were grounded, and other health services were severely curtailed because hospitals lacked basic medical supplies. Drug production and distribution within the country came to a halt. Tuberculosis treatment was interrupted for lack of drugs. ${ }^{1}$ Immunisation programmes were put on hold for lack of vaccine transport and cold chain maintenance. Antenatal, postnatal and emergency obstetric care, including the care of newborns and children often was skipped or delayed because people could not get to them. Consequently, children, women and older people were among the most affected.

Health was affected in other ways, too. Overcrowding of limited public transport led to accidents and deaths on hilly roads. The lack of cooking fuel meant that people used wood fires instead, adding to indoor and outdoor air pollution. No aspect of everyday life was left untouched.

The blockade added to the misery of earthquake survivors. Healthcare workers and supplies were simply not available or available only at exorbitant prices. Reconstruction was delayed due to lack of resources, tied directly to the blockade and fuel crisis. Those living in tents during the winter faced freezing temperatures and little warmth. ${ }^{8}$

Added to the already damaged infrastructure from the earthquake, the disruption caused by the fuel crisis jeopardised the hard-won achievements in maternal and child health, polio elimination and tuberculosis control. Of global concern, outbreaks of new or re-emerging diseases that might have occurred in Nepal during the blockade would have posed a threat to India and other neighbouring countries. Some of the progress made toward the Millennium Development Goals is feared lost, which may affect the achievement of the health-related Sustainable Development Goals. ${ }^{1}$

Nepal's experience of a health crisis caused by a border blockade is not unique. A blockade of Burundi in 1996 decreased fuel supply and triggered scarcities of food, medicine and all general supplies, leading to price hikes and a thriving black market. ${ }^{5}$ In the Gaza Strip during the blockade of Palestine following the 2006 elections, limitations on transport caused shortages in treatment facilities that damaged health and quality of life. ${ }^{6}$ Economic and political blockades are considered a form of collective punishment to the entire population. ${ }^{7}$ The larger point is that 'fuel crisis' whatever the cause, easily translates to 'health crisis,' which worsens with continuing fuel shortages.

Further studies on the impact of the blockade may give a more complete picture of the effect of the fuel crisis on Nepal and may benefit countries facing similar conditions in the future. Regardless, it is already evident that the global health community should pay as much attention to blockades and fuel crises as they do to earthquakes.

Acknowledgements The authors acknowledge the initial support from professor Paras K Pokharel during the preparation of the paper.

Contributors SSB and HG conceptualised the paper, revised and finalised the draft and approved the final version to be submitted.

Competing interests None declared.

Provenance and peer review Not commissioned; externally peer reviewed.

Data sharing statement No additional data are available.

Open Access This is an Open Access article distributed in accordance with the Creative Commons Attribution Non Commercial (CC BY-NC 4.0) license, which permits others to distribute, remix, adapt, build upon this work noncommercially, and license their derivative works on different terms, provided the original work is properly cited and the use is non-commercial. See: http:// creativecommons.org/licenses/by-nc/4.0/

\section{REFERENCES}

1. Lamichhane J. Health consequences of the blockade in Nepal. Lancet 2015;386:10010.

2. Singh M. India and Nepal: neighbours trapped by apprehensions. The Hindu Centre for Politics and Public Policy 30 June 2016. http:// www.thehinducentre.com/multimedia/archive/02922/109_India_ and Nep 2922002a.pdf (accessed 31 Jul 2016).

3. Bhattarai TN. Remembering the 1989 blockade, Nagarik 05 October 2015. http://nepalitimes.com/article/from-nepali-press/Remembering the-1989-blockade,2651 (accessed 31 Jul 2016).

4. Nielsen MJ, Ferguson S, Joshi AK, et al. Post-earthquake recovery in Nepal. Lancet Glob Heal 2015;4:e161.

5. Hoskins E, Nutt S, Watson TJ Jr. The Humanitarian Impacts of Economic Sanctions on Burundi, Providence: The Thomas Watson Jr. Institute for International Studies 1997;13-91.

6. Abu-el-noor NI, Abu-el-noor MK. Impact of the blockade concerning the health-related quality of life on prostate cancer survivors residing in Gaza Strip, Palestine. Asian J Pharmacy Nurs Med Sci 2013;01:7-17

7. United Nations Office for the Coordination of Humanitarian Affairs occupied Palestinian territory. Locked In: The humanitarian impact of two years of blockade on the Gaza Strip. Special focus. East Jerusalem, 2009;2.

8. AFP. Nepalese face winter in tents as parties squabble, Taipe Times 13 December 2015. http://www.taipeitimes.com/News/world/ archives/2015/12/13/2003634713/1 (accessed 21 Jul 2016). 